\title{
2 Global Orchid Industry
}

Floriculture has emerged as an immense entrepreneurial opportunity for small and marginal farmers and a way forward to earn foreign exchange. Floriculture business deals with cut flowers, pot plants, cut foliages, seeds, bulbs, tubers, rooted cuttings and dried flowers or leaves. Major floricultural crops traded internationally include roses, carnations, chrysanthemums, gerberas, gladiolus, gypsophilas, liatris, nerines, orchids, achillea, anthuriums, tulips and lilies. With the increase demand for flowers, floriculture has become one of the important commercial trades in Indian Agriculture. Therefore, commercial floriculture has emerged as a high-tech activity taking place under controlled environments inside greenhouses. Indian floriculture is now viewed as a high growth industry, particularly as the liberalization of industrial and trade policies have paved the way for development of export oriented floriculture. The floral industry is a highly dynamic business. The characteristics of varieties, the origin of production, production technologies, markets and retailing systems as well as individual products are all undergoing continuous change, while challenging the adaptive capacity of the actors involved. In a slowly but steadily growing world market, new developing country exporters are increasing market share at the expense of existing producers. These producers try to remain ahead by increasing productivity and through diversification and innovation. Kenya, Ecuador and Zimbabwe, the rapidly rising exporters of the last decade, have become established suppliers to their ambitious new competitors including China, India, The Republic of Korea, Malaysia, Malawi, Mexico, Palestine, Peru, South Africa and Zambia. India is the world's fastest growing destination for tourism. Flower consumption growth rises by up to $30 \%$ per annum and numerous festivals, along with increasing modernization and per capita income, make India a floral super power of the future. Our country is emerging as the world's fastest growing flower and gardening market.

About 190 thousand ha area has been brought under flower cultivation during 2011-12. During 2010-2011, the production of flowers was estimated to be 870.4 metric tons of loose flowers and 43417.5 million of cut flowers. The government of India has considered floriculture as a sunrise industry and accorded it 100\% export oriented status. The country has reached the ability to export 30926023 metric tons of floriculture products to the world for the worth of Rs. 365.32 crores in 2011-12. USA, Germany, UK, Japan, Canada and UAE were the major consumers of Indian floriculture. While the Indian floriculture industry is likely to reach the Rs. 8000 crore mark by 2015, it currently stands at about Rs. 3700 crores with the share of $0.65 \%$ in the international floriculture sector which is likely to reach $0.89 \%$ by 2015 .

\subsection{Global Orchid Trade}

Imports and exports of floriculture products from all round the world are increasing year by year because industry professionals in India are always seeking new products, 
techniques and devices that are effective and economic. As a result, floriculture trade is flourishing and research centres and species nurseries have turned into a promising business. In addition, India has the advantage of favourable agroclimate, low cost labour, arable land, skilled manpower, proximity to emerging floriculture markets such as Japan, Australia and the Middle East, and conducive growing weather during the peak time of worldwide demand in November - March in the northern plains as well as mild climate in the southern part of India throughout the year for tropical flowers. The recent export situation of orchids focusing on India is given below (Tab. 2.1)

Tab. 2.1: Export of orchids from India (Rs. in lacs \& quantity in MT)

\begin{tabular}{llllllc}
\hline Country & \multicolumn{2}{c}{ 2010-2011 } & \multicolumn{2}{c}{ 2011-12 } & \multicolumn{2}{c}{ 2012-13 } \\
\hline Bahrain & 0.00 & 0.00 & 0.00 & 0.00 & 0.20 & 1.43 \\
Maldives & 0.04 & 0.18 & 0.13 & 0.56 & 0.27 & 0.96 \\
Kenya & 0.00 & 0.00 & 0.04 & 0.05 & 0.06 & 0.09 \\
Sri Lanka & 0.00 & 0.00 & 0.00 & 0.00 & 0.02 & 0.05 \\
Quatar & 0.00 & 0.00 & 0.01 & 0.02 & 0.00 & 0.00 \\
Singapore & 4.77 & 3.08 & 0.00 & 0.00 & 0.00 & 0.00 \\
UAE & 0.04 & 0.06 & 0.20 & 0.35 & 0.00 & 0.00 \\
\hline
\end{tabular}

Source: DGCIS Annual report

The orchid has taken a significant position in the cut flower industry due to its attractiveness, long shelf life, high productivity, right season of bloom, ease of packing and transportation. Orchids account for a large share of global floriculture trade both as cut flowers and as potted plants and are estimated to comprise around $10 \%$ of the international fresh cut flower trade. The average trade value of fresh cut orchids and buds trade during 2007-2012 was US\$ 483 million. In 2012, there were more than 40 and 60 exporting and importing orchid countries, respectively around the world, and the total size of the global trade was US\$ 504 million (Tab. 2.2).

Tab. 2.2: Value of fresh cut orchids and buds global trade (2007-2012) (Unit: Million US\$)

\begin{tabular}{lllllll}
\hline Year & 2007 & $\mathbf{2 0 0 8}$ & $\mathbf{2 0 0 9}$ & $\mathbf{2 0 1 0}$ & $\mathbf{2 0 1 1}$ & $\mathbf{2 0 1 2}$ \\
\hline Import & $233,734,023$ & $252,647,645$ & $232,568,129$ & $251,445,523$ & $265,702,077$ & $267,196,847$ \\
Export & $230,470,421$ & $238,702,950$ & $217,781,745$ & $227,389,789$ & $244,996,271$ & $237,543,797$ \\
Total & $464,204,444$ & $491,350,595$ & $450,349,874$ & $478,835,312$ & $510,698,348$ & $504,740,644$ \\
\hline
\end{tabular}

Source: Department of Foreign Trade, Thailand (2013) 
The Netherlands is the top orchid exporting country in the world $(39.67 \%$ of world orchid market) followed by Thailand (28.41\%), Taiwan (10\%), Singapore (10\%) and New Zealand (6\%). Importing countries are mainly Japan (30\%), UK (12\%), Italy (10\%), France (7\%) and the USA (6\%). The total orchid cut flower trade of the world mostly consists of $85 \%$ Dendrobium species and 15\% Phalaenopsis and Cymbidium species, and Asia is the main source of orchid to enter the world market (Cheamuangphan et al, 2013)

Major markets for orchids in Asia are occupied by Japan and Singapore. The total imports of orchids by Japan accounted for US\$ $57.4 \mathrm{mn}$ in 2008 making it the largest importer of orchids in the world. The main sources for these imports include Thailand, Taiwan, New Zealand and Malayasia which together account for as much as $96.5 \%$ of the total orchids imports by Japan in 2008. Imports by Singapore of fresh orchids amounted to US\$ $6.5 \mathrm{mn}$ in 2007 with Malayasia, Thailand and Taiwan being the main sources of imports for the country. In contrast, imports of fresh orchids by Singapore from India were only US\$ 1379.3 representing a share of $0.02 \%$ of the country's total imports of the product in 2007 (Tab. 2.3). This clearly indicates that there are vast possibilities for increasing India's exports to Singapore particularly considering the proximity of the country and India's East Policy.

Tab. 2.3: Imports of orchids by Singapore (2007)

\begin{tabular}{lll}
\hline Country & Value (US\$) & Share (\%) \\
\hline Malayasia & 5422069.0 & 83.03 \\
Thailand & 520699.7 & 7.97 \\
Taiwan & 307596.2 & 4.71 \\
Mauritious & 149655.2 & 2.29 \\
Indonesia & 117241.4 & 1.90 \\
Netherlands & 8275.9 & 0.13 \\
New Zealand & 2758.6 & 0.04 \\
India & 1379.3 & 0.02 \\
China & 699.7 & 0.01 \\
Total imports & 6530344.8 & 100.00 \\
\hline
\end{tabular}

Source: International Enterprise Singapore 


\subsection{Trend in Growth}

\subsubsection{Cymbidium}

Cymbidiums are among the most popular winter and spring blooming semi-terrestrial orchids originating from tropical and subtropical Asia; covering North Eastern India, China, Japan, Malayasia, the Philippines, the Borneo islands and North Australia, usually grown in cooler climates at high elevations. Cymbidiums are highly valued for genetic resources, cut flowers, hanging baskets, potted plants and herbal medicines. Cymbidium has been considered the top commercial orchid in Europe for many years. They fetch the highest price in the international markets of which major destination include Asian markets of Singapore and Japan or the Dutch market. Cymbidiums imported from the Netherlands fetched as much as US\$ 11.18 per stem in Singapore and those imported by Japan from New Zealand fetched US\$ 3.33 per stem. As far as the Dutch Auction market is concerned, the cymbidiums fetched the highest value, averaging Euro cents 331 per stem during 2003-2007 (Tab. 2.4).

Tab. 2.4: Average annual prices at Netherlands auction (2003-2007) (Euro cents / stem)

\begin{tabular}{lllll}
\hline Orchids & $\mathbf{2 0 0 3}$ & $\mathbf{2 0 0 5}$ & $\mathbf{2 0 0 7}$ & Average price \\
\hline Phalaenopsis & 38 & 46 & 37 & 40 \\
Cymbidium (Big bud) & 330 & 334 & 329 & 331 \\
Cymbidium (Small bud) & 138 & 148 & 140 & 142 \\
Paphiopedilum & 58 & 52 & 63 & 58 \\
\hline
\end{tabular}

Source: CBI Market Survey, The Cut Flowers and Foliage Market in the EU

In India, the Arunachal hills, Sikkim and Darjeeling hills with cool summer nights and monsoonal summer rain are ideal for cymbidium cultivation. The growth of orchid exports from the north eastern hill region, especially Sikkim, would provide opportunities for employment as well as the development of supporting industries like packaging, cold storage and transportation. East Sikkim has been declared an Agri Export Zone exclusively for production of cymbidium orchids. In Sikkim, more than 250 hybrids of cymbidium orchids are commercially cultivated in and around 25 ha of land and about 5 lakhs spikes are produced annually.

\subsubsection{Dendrobium}

Dendrobiums are popular flowering potted plants and cut flowers around the world due to their floriferousness, wide range in flower color, size and shape, year round 
availability and lengthy vase life. Hawaii, California and Florida are major potted Dendrobium growing regions in the United States. The wholesale value of sales for this commodity in Hawaii has been established for several decades and sales increased from US \$ 2.4 million in 1991 to US\$ 5.6 million in 2000 (Tab. 2.5).

In the Netherlands, production of potted orchids is now 40 to 50 million units with Dendrobium increasing in popularity. Imports from Thailand, the worlds largest exporter of tropical cut orchids and second largest supplier to the EU, accounted for $22 \%$ of supplies to the EU. Thailand holds a particularly strong position in Dendrobium orchids.

Tab. 2.5: Quantity of consumption and wholesale value of sales of potted Dendrobium in Hawaii (Johnson, 1999).

\begin{tabular}{llll}
\hline Year & Number of pots sold & Value (US \$) & Number of growers \\
\hline 1985 & 0.2 millions & 1.1 million & 88 \\
1991 & 0.4 millions & 2.4 million & 47 \\
2000 & 1.0 million & 5.6 million & 69 \\
\hline
\end{tabular}

Tab. 2.6: Orchid price in Singapore (US\$)

\begin{tabular}{lll}
\hline Product details & Origin & Price /stem \\
\hline Orchid Cymbidium & Malaysia & 1.97 \\
Orchid Cymbidium & Netherlands & 11.18 \\
Orchid Cymbidium & Taiwan & 5.26 \\
Orchid Dendrobium XL & Thailand & 0.46 \\
Orchid Dendrobium L & Thailand & 0.39 \\
Orchid Dendrobium M & Thailand & 0.33 \\
Orchid Dendrobium S & Thailand & 0.26 \\
Orchid Oncidium XL & Malaysia & 0.72 \\
Orchid Oncidium L & Malaysia & 0.59 \\
Orchid Oncidium M & Malaysia & 0.39 \\
\hline
\end{tabular}

Source: Market News Service-Week 14, 2009, ITC

\subsubsection{Phalaenopsis}

Phalaenopsis is the second most valuable and popular flowering potted plant and cut flower around the world due to their easy cultural practices, diversity in flower colour, size and shape, year round availability, delicacy and longer vase life. It is commer- 
cially grown in Germany, Japan, The Netherlands, Taiwan and United States. In the United States, $75 \%$ of all orchids purchased are phalaenopsis and about 13,500,000 phalaenopsis were sold in 2005 in United States. The export value of phalaenopsis from Taiwan to the United States increased from \$8 million in 2005 to \$13 million in 2006. Worldwide turnover of Taiwanese phalaenopsis increased from $\$ 27.5$ million to \$35.4 million from 2005 to 2006.

\subsubsection{Other Tropical Orchids}

Vanda is widely distributed throughout Australasia from China through the Philippines, Indonesia, Malaysia, New Guinea and Australia, Myanmar, Thailand, India and Sri Lanka. In the world tropical orchid trade, Dendrobium is the most dominant crop in addition to Mokara, Oncidium, Aranthera, Aranda, Vanda, Arachnis, Renanthera, Ascocenda, Phalaenopsis, Cattleya and Paphiopedilum which are being grown as cut flowers and potted plants. Thailand is the largest world exporter of tropical orchids. China is the largest consumer of orchid cut flowers (7,493 tons from Thailand) followed by Japan, USA, Italy, India, Taiwan, Vietnam and the Netherlands at 4,407, 2892, 2395, 1830, 983, 793 and 689 metric tons, respectively. Other significant orchid genera being exported from Thailand were Mokara, Aranthes, Aranda, Oncidium, Vanda, Arachnis and Ascocenda with market shares of 3.69, 0.52, 0.48, 0.44, 0.13, 0.01 and $0.01 \%$ of total export value respectively (Tab. 2.7).

Tab. 2.7: Orchid export from Thailand in 2009 (\% share of total export value)

\begin{tabular}{llll}
\hline \multicolumn{2}{c}{ Cut orchid } & \multicolumn{2}{c}{ Orchid plant } \\
\hline Orchid genera (20) & Value shared (\%) & Orchid genera (211) & Value shared (\%) \\
Dendrobium & 94.73 & Dendrobium & 51.4 \\
Mokara & 3.69 & Phalaenopsis & 25.5 \\
Aranthera & 0.52 & Vanda & 8.9 \\
Aranda & 0.48 & Mokara & 3.7 \\
Oncidium & 0.44 & Oncidium & 3.1 \\
Vanda & 0.13 & Cattleya & 2.7 \\
Arachnis & 0.01 & Ascocenda & 1.2 \\
Ascocenda & 0.01 & Epidendrum & 0.6 \\
& & Cymbidium & 0.3 \\
& & Rhyncostylis & 0.3 \\
& & Spathoglottis & 0.3 \\
& & Paphiopedilum & 0.2 \\
& & Others & 1.8 \\
\hline
\end{tabular}


Considering the import value of orchid plants, Japan was also the largest importer of Thai orchid plants at US\$ 2.4 million worth followed by the Netherlands, USA, Germany, Rep. of Korea and Vietnam with values of 1.6, 1.4, 1.0, 0.9 and US\$ 0.9 million respectively. In 2009, Thailand exported 211 genera of orchid plants. Dendrobium and Phalaenopsis plants were the most important orchid genera for exports with market shares of 51.4 and $25.5 \%$, respective. Other important orchid genera exported from Thailand were Vanda, Mokara, Oncidium, Cattleya and Ascocenda with market shares of 8.9, 3.7, 3.1, 2.7 and 1.2\% of total export value, respectively (Lekawatana, 2010). 